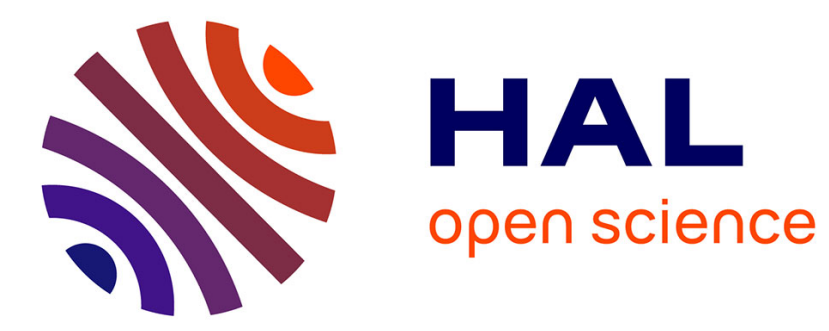

\title{
"I attack not him": the Rhetorical Treatment and Political Issue of (not) Naming the Enemy in Ovid's Last Works
}

Hélène Vial

\section{- To cite this version:}

Hélène Vial. "I attack not him": the Rhetorical Treatment and Political Issue of (not) Naming the Enemy in Ovid's Last Works. Arethusa, 2020, 53, pp.213-233. hal-02370663v2

\section{HAL Id: hal-02370663 https://hal.uca.fr/hal-02370663v2}

Submitted on 25 Apr 2022

HAL is a multi-disciplinary open access archive for the deposit and dissemination of scientific research documents, whether they are published or not. The documents may come from teaching and research institutions in France or abroad, or from public or private research centers.
L'archive ouverte pluridisciplinaire HAL, est destinée au dépôt et à la diffusion de documents scientifiques de niveau recherche, publiés ou non, émanant des établissements d'enseignement et de recherche français ou étrangers, des laboratoires publics ou privés. 


\title{
"I attack not him": the Rhetorical Treatment and Political Issue of (not) Naming the Enemy in Ovid's Last Works
}

\begin{abstract}
The texts written on the shores of the Black Sea reveal to us in a crucial way the challenge represented by the free speech of which Ovid himself claims to have made excessive use. Ovid grapples with this issue in his treatment of an enemy's name in the works of relegatio, where he affirms the primacy of language over the political meaning. But the force of poetry multiplies the political impact, for what is then boldly expressed is the invincible independence of a work that stands up-first to one princeps and then to another.
\end{abstract}

In the title of this article, the expression "I attack not him" is taken from Sergio Casali's article “Quaerenti plura legendum: on the Necessity of 'Reading More' in Ovid's Exile Poetry" (Casali 1997.107). Yet one might legitimately posit a different subtitle: "The Reclaiming of Lost Freedom of Speech." What was this freedom for Ovid when he wrote the Tristia, the Ibis and the Epistulae ex Ponto after his disgrace and in a phase of his life where, until a certain point, he had hoped that he would be recalled? I think the texts written on the shores of the Black Sea reveal to us in a crucial way the challenge represented by the free speech of which Ovid himself claims to have made excessive use. How could a man bear to have been relegated to the ends of the Empire because of his reason for living, the poetic exercise of a bold and indomitable licentia? How could he use this license, which was now all he had left, and which, day after day, saved him from despair, to have his sentence softened or even commuted, without giving up the independence that defined his entire journey as an author? These are the questions I would like to explore here. 
For my investigation I will adopt a particular approach to this subject that may seem paradoxical, since I will speak of passages in which it is silence that speaks or where the absence of a word produces an effect. Silence and absence are relative, of course, since the poem continues and the omitted word is replaced by one or more other words. The word that Ovid suppresses is the name - the real one - of an enemy. In this paper, I would like to observe the consequences, in terms of the effectiveness and freedom of poetic speech, of the refusal to name this man who, though fleetingly evoked in the collections of letters, is the exclusive object of the Ibis.

There is also a second paradox. When we read the works Ovid wrote while in Tomis, we are struck by the flow of proper names, and in particular character names, whether they belong to Ovid's own time, to the historical past, or to the world of myth; this mixture of reality and fiction bears some effects and significance for their poems. The Tristia and ex Ponto are filled with moments of name-dropping; the Ibis, though, is a flood of proper names borrowed from mythological and historical fabulae. But more precisely, the intrusion of names into the poetic space only draws more attention to those extremely rare moments when a name is expected but is missing. The resulting surprise suggests that the absence is meaningful, especially since the missing name is that of an enemy who should probably be identified with the same person in almost every case — and in a sense, in every case.

Let us first observe the relevant passages following their order in the corpus. There are nine appearances of the figure I will call the "anonymous adversary," six of which are in the Tristia, one in the Ibis, and two in the ex Ponto. The first one is addressed by Ovid to his wife (Tristia 1.6.7-16):

Tu facis ut spolium non sim nec nuder ab illis naufragii tabulas qui petiere mei. 
Vtque rapax stimulante fame cupidusque cruoris incustoditum captat ouile lupus,

aut ut edax uultur corpus circumspicit ecquod sub nulla positum cernere possit humo, sic mea nescio quis, rebus male fidus acerbis in bona uenturus, si paterere, fuit.

Hunc tua per fortes uirtus submouit amicos, nulla quibus reddi gratia digna potest ${ }^{1}$.

It is you who makes sure that I am not stripped, not left naked, by those who wanted to take possession of the planks of my shipwreck. And as the wolf, eager to steal, excited by hunger, greedy for blood, seeks to take a sheepfold without a guardian, or as the voracious vulture looks around to see if it might spot a corpse not covered with earth, so someone, I do not know who, betraying my trust now that I am in adversity, was ready to attack my property if you had let him do so.

A scenario with linguistic features familiar from the Ibis are already present in the Tristia, and the man whom Ovid refuses to name draws special attention even if he remains within a collective of malicious individuals.

The eighth elegy of the same book is addressed in the third and especially in the second person - as the Ibis will do - to a certain fallax man (11) who is accused of betraying his longstanding friendship with the poet during his exile and cruelly depriving him of his support (Tr. 1.8.9-10): sum deceptus ab illo / laturum misero quem mihi rebar opem (I was deceived by the one I thought was destined to help me in my misfortune ). The end of the 
poem, however, expresses hope that the individual in question will change his attitude and carry out his officium (50).

The eleventh elegy of Book 3, a poem full of pain and anger, most clearly anticipates the Ibis both in form and content, especially, the alternation of the pronouns "you" and "he." In the back-and-forth of pronouns, however, the second person form is clearly dominant, through which the poem violently attacks a man (aliquis, 19), accusing him of verbally attacking the poet and, more precisely, using his eloquence (ora diserta, 20) to question his moral integrity (mores $[\ldots]$ meos, 20). ${ }^{2}$

Elegy 9 of Tristia Book 4, written entirely in the second person, is the first to tackle the question of the name head on, at the same time as it explicitly previews the Ibis (Tr. 4.9.12): nomen facinusque tacebo, / et tua Lethaeis acta dabuntur aquis (I will keep your name and your crime secret, and your deeds will be delivered to the waters of Lethe; also 25f. and 31f.). Silence and forgetfulness are what the poet promises his enemy if he weeps and repents; if he does not, he will take revenge and, if poetry is all he has left, then his revenge will be literary and the world will forever know of a crime (26) that is not further defined. But for the time being, he can still "hide his name" (licet huic nomen dissimulare suum, 32).

Elegy 8 of Book 5 is again addressed to a malicious man (improbe, 3) referred to in line 2 as te [...] inferius quo nihil esse potest (you, than whom nothing could be lower). The details of his crime are unknown (5.8.10): Imposito calcas quid mea fata pede? (Why are you trampling on my destiny?). The poet, as he had already in $\operatorname{Tr} .3 .11$, here threatens him with a reversal of fortune, a great law of human life.

Finally, we find a nescio quis in the first line of the eleventh elegy of Book 5, addressed to Ovid's wife. The poet reproaches his target not for a betrayal,but rather over a matter of terminology: the man called Ovid's wife exulis uxorem (the wife of an exile, 2), and 
it is in response to this "false term" (nomine mendaci, 30) that Ovid wrote this letter in which he asks the anonymous man to renounce the term exul.

Composed alongside some of the Tristia's letters, the Ibis is a special case. It consists of 644 lines addressed to a "villain" whose crime encompasses all those of the other "villains" in his poems, including lust for an exile's property, betrayal of friendship, and verbal attacks. The ibis of the poem embodies the improbus (the term appears in line40), and an attack whose length and violence is unprecedented in Ovid's work is carried out against this individual who is not only left unnamed - though he will be named later if he continues his actions, Ovid tells us - but receives, and is the only one to receive, a fictional name, "Ibis" (Ibis 1-10; 51-52; 6162):

Tempus ad hoc lustris bis iam mihi quinque peractis,

omne fuit Musae carmen inerme meae,

nullaque, quae possit, scriptis tot milibus extat

littera Nasonis sanguinolenta legi,

nec quemquam nostri nisi me laesere libelli :

artificis periit cum caput arte sua.

Vnus - et hoc ipsum est iniuria magna - perennem

candoris titulum non sinit esse mei.

Quisquis is est (nam nomen adhuc utcumque tacebo),

cogit inadsuetas sumere tela manus.

$[\ldots]$

et neque nomen in hoc nec dicam facta libello

teque breui qui sis dissimulare sinam.

$[\ldots]$ 
et, quoniam qui sis nondum quaerentibus edo,

Ibidis interea tu quoque nomen habe.

Up to now (two times five lustra already lived), my Muse has always sung without weapons. Out of so many thousands of letters drawn by Naso, none can be read that is stained with blood. No one was hurt by my little books, except me, the artist deprived of life at the same time as his art. Only one individual (and it is a major insult in itself) refuses to let my title as a pure man last. Whoever it is (because anyway I will keep his name silent here again), he forces my inexperienced hands to take up arms. [... In this little book I will not say your name or your actions: no, I will let you hide your identity, still a little bit. [...] Since I am not yet revealing your identity to anyone who would like to know it, be named Ibis as well in the meanwhile.

The question of the name comes up again (643-644): Postmodo plura leges et nomen habentia uerum / et pede quo debent acria bella geri (Later on, you will read more, with both your real name and the rhythm required by the violence of wars).

The furious invective of the Ibis, which centers on an enormous list of mostly mythological, sometimes historical tortures wished against "Ibis," seems to absorb all the "anonymous adversaries" of the Tristia into a single figure who contains, embodies and surpasses them. When one considers the final two references to the unnamed enemy, which follow upon the Ibis in the ex Ponto, one can see that the Ibis has already said everything. The first of these passages is a bit muffled; the first four lines of elegy 9 in Book 3 include a nescio quem (2) who reproaches the poet for always talking about the same things in his letters (such as the burden of exile and the hope that it will end). The second passage, from Tristia 4.3 , is entirely addressed to a man, who, like the addressee of Tristia 1.8 and the man 
identified as "Ibis," has betrayed his friendship with the poet by spurning and denigrating him after his exile. The passage is imbued with a patchwork of formal and thematic elements from the Ibis; it also raises, with interesting variations, the matter of one's name and its abolition for both the enemy and the poet:

\author{
Nomine non utar, ne commendere querela, \\ quaeraturque tibi carmine fama meo \\ I will not use your name, for fear that my complaint might enhance you and my poem \\ make you famous
}

Dissimulas etiam nec me uis nosse uideri quisque sit audito nomine Naso rogas You go so far as to hide, you don't want to seem to know me, and when you hear my name you ask who Naso is $(\operatorname{Tr} .4 .3 .3-4 ; 9-10)$

:. When, at the end, this elegy evokes the fortune that can at any moment reverse both destinies, it leads us, in lines 51-54, to the word ibis itself(Pont 3.9.51-54): "Litus ad Euxinum" si quis mihi diceret "ibis / et metues arcu ne feriare Getae," / "I, bibe" dixissem "purgantes pectora sucos / quicquid et in tota nascitur Anticyra." (If I had been told : "You will go to the shore of the Pontus and you will live in fear of being struck by the bow of the Geta," "Go," I would have replied, "drink the potions that purge the mind and everything that the whole Anticyra produces").

These ironic and poignant words, in which the anonymous enemy and the drama of exile meet, lead us to the heart of my subject: the rhetorical stakes in both poetics and politics of the refusal to give the enemy his real name. Indeed, they answer the question regularly asked by commentators as to who this man whose name Ovid refuses to tell us is and whether 
or not it is the same man each time? After all, beyond the small wavering about the details given about the enemy and/or what he has done, isn't it always or almost always the same name that hides behind aliquis or nescio quis? Some critics, who have studied all possible names with care and erudition, have said that Ovid does not name this enemy because it would be dangerous as he is the princeps. Over several years. Alessandro Schiesaro (2011.79150) has tested, refined and enriched a fascinating hypothesis that was ultimately presented in a masterful 2011 article entitled "Ibis redibis,"; his theory was partially presented in 1997 in Sergio Casali's paper, "Quaerenti plura legendum," cited at the opening of this article.

Schiesaro's article opens with a beautiful quote from Stéphane Mallarmé (1891.60): “Nommer un objet c'est supprimer les trois quarts de la jouissance du poème qui est faite du bonheur de deviner peu à peu ; le suggérer, voilà le rêve." ${ }^{3}$ These words paradoxically and perhaps unintentionally point to the problem of identifying the unnamed enemy with Augustus. When we read Schiesaro - and Casali_ our first reflex is to think that, naturally, Ovid directs all his rage against the anonymous figure whose presence recurs throughout the works of relegatio and who becomes a focus of the Ibis, the very man who exiled him and who, already before that, represented, politically and ideologically, the polar opposite of his way of thinking. Then we see in the refusal to name this enemy an unprecedented example of an author's self-imposed restriction of his freedom of speech, the motivations for which seem fundamentally ambivalent, falling somewhere between caution and provocation. But at the same time, when we read the first sentence of Schiesaro's article (2011.79: "Could Ibis really be anyone but Augustus?"), we experience the shock of witnessing the annihilation of the entire richness of the passages where Ovid erases the name of the one who hurt him and implicitly asks us to transform this erasure into an active element of our reading, starting from the principle that the choice not to name the adversary is invested with a literary function that 
has something to tell us about the poet and the new inflection given to his work through the relegatio.

It is not a question of blindly effecting a spirit of contradiction that would lead us to object that the "anonymous adversary" is not Augustus, and still less a matter of relying on biographical details that would make the identification with the princeps impossible, or of basing this impossibility on the deference shown him in these passages and, more broadly, in Ovid's exilic works. These contradictions are of no real value; Ovid's approach to Augustus is marked by a fundamental ambiguity that is perhaps in a sense the primary reason for his banishment. Rather, what is interesting is to restore the richness of this character whom Ovid ostensibly does not name, to go beyond the "I attack not him" interpreted as an "I attack him," and does so by reintegrating the non-enunciation of the real name within its rhetorical and poetic context.

We have known since Homer that silence is sometimes more eloquent than words, especially in the midst of a crowd. Laurent Pernot's (2018) recent book L'Art du sous-entendu richly and insightfully explores the power of this idea, which, in an oratorical context, consists of retaining and abolishing speech. I am thinking in particular of the chapter "Fauxsemblants grecs sur Rome" ("Greek Pretenses on Rome", one of whose subsections is entitled "L’éloquence du silence" (“The Eloquence of Silence"). ${ }^{4}$

Each of Ovid's works is conceived of as a kaleidoscope that reveals the heuristic power of its object by offering many varying, fragmentary visions of it. Thus doesthe Metamorphoses operate, which offers more than two hundred variations of the metamorphosis of one form into another, in order to draw the provocative image of a world governed by passions that, at their climax, get imprinted on bodies. The poems written in Tomis also function in this way. Yet these works, through the multiplication of recipients, angles and formulations, deliver a new vision of their object. This object is exile, and to refuse to name 
an enemy, to name the enemy, is one of the tools, particularly original and fertile, that Ovid uses to express in a completely new way the existential journey of being exiled. In other words, Ovid brings to a higher, poetic, degree the coldly biographical horror of being uprooted from Rome and relegated to a life on the shores of the Black Sea. The Tristia and ex Ponto offer variations on the theme of erasing the hostile individual's name. These variations all heighten the pathos of exile..

What binds these variations together, crystallizes them, and makes them understandable is the Ibis, and especially its prologue, which is the only place where Ovid not only chooses not to name the enemy explicitly, but also gives the enemy another name. However, this name carries multiple determinations that inform us about the functions of the poem; calling the enemy "Ibis" means writing intertextually (with explicit reference to the Ibis of Callimachus). It also means describing how the name works (the ibis is an animal that is both dirty and clean, cleansing the streets by eating garbage then purging itself by an enema). Finally, it can designate a political target (the ibis is the bird of Mercury, with whom Augustus was identified before Apollo, and who is mentionedironically at Metamorphoses 5.331, where Ovid shows him becoming an ibis to escape Typhaeus). But beyond all these anchors, "Ibis" is also the verbal form ibis, meaning "you will go," a connection confirmed by the ninth elegy of Book 3 of the ex Ponto in the derisive, desperate passage quoted above (Pont 3.9.51-54). To give the name "Ibis" to the man who strives to exacerbate the suffering of the exiled is to identify the term with the relegatio itself and to the heart-wrenching experience that it represents - and of course, what makes "Ibis" such an ideal name is that reading it backwards gives us sibi. Then the anonymous adversary is, indeed, always the same: it is the existential experience of exile. And, if the adversary's real name is left unsaid, it is certainly so in part because to reveal it would be dangerous - and this silence obviously refers us to another silence, the one that surrounds the cause of Ovid's exile—-but it is mostly 
because being exiled is an aberration, a monstrosity, an adynaton, impossible to say, just as metamorphosis is.

And yet, in his own way, Ovid says it. This leads me to suggest that the experience described in the Tristia, the Ibis and the ex Ponto is at least as poetic as it is biographical, and that the issue of the name plays an essential role in it. To call the enemy who is stripped of his nomen $[. .$.$] uerum "Ibis" is also to take revenge on him, a revenge that is all the more radical$ and definitive for being purely verbal. And this approach, which forms the basis for the entire Ibis, is also used throughout the Tristia and ex Ponto. The character who is not named and who is always symbolically the same since he embodies exile, is also threatened and attacked by the hundreds of proper names that accumulate around him. In this respect, the most meaningful text is once again the Ibis, which deploys hundreds of names from mythology and sometimes history around "Ibis," causing him to be both fragmented and over-determined.

For example, Ibis 309-338 perfectly illustrates the use of exempla consisting of character names that are not stated, leaving the reader to identify them according to the principle of ambages - another kind of poetic withholding of names, placed at the heart of the Ibis to double its effects - as well as of character names that are stated to help us solve the puzzles. What are we being told by this onomastic accumulation, which, far from helping us, ultimately crushes us, drowns us, atomizes us, and consumes us, just as it does "Ibis"? We are being told that, in the face of the horror of exile and the anger it provokes, poetic invention remains and that it is the only remedy when all is lost, but that it is also absolutely effective. We are further told that this invention, based on trust in the uerba, boldly affirms its ability to preserve the poet's freedom of speech, even beyond his exile, and that this ability is expressed in a particularly provocative way in the sovereign choice of whether or not to give his adversary his real name. 
In conclusion, it does not matter, whether or not the anonymous adversary is Augustus, Tiberius, or perhaps Augustus and Tiberius (I mean Augustus as identified with the ideological line of thought that led him to choose Tiberius to succeed him). It does not matter because the treatment of the enemy's name in the works of relegatio affirms the primacy of the poetic language over the political meaning. But the force of poetry multiplies the political impact, for what is then boldly expressed is the invincible independence of a work that stands up-first to one princeps and then to another. The carmen that refuses to identify another man's actions serves as a symbolic nota which, responding to the dramatic deprivation of rights that is exile, compensates for it a hundredfold by depriving the enemy of a fundamental right, that of being named. ${ }^{5}$ Not to say his name "does not erase the name from the public discourse, $[\ldots]$ but imposes a vitiated circulation and strongly reduces its social capital, a reduction that is accompanied by a feeling, also eminently relational and interpersonal, of shame" (Lentano 2018.171). ${ }^{6}$ This action is explicitly described in a distic of the Ibis where, Ovid makes this wish for "Ibis," who brutally throws the poet's name about the Roman forum (443-444): aut eques in medii mergare uoragine caeni, / dummodo sint facti nomina nulla tui (On horseback, may you be swallowed up in a muddy abyss, provided that no renown - or, more literally, no noun, no name - attaches itself to the event).

\section{Bibliography}

André, Jacques, ed. 2002. Pontiques. Paris.

. 2003. Contre Ibis. Paris.

- 2008. Tristes. Paris.

Casali, Sergio. 1997. "Quaerenti plura legendum: on the Necessity of 'Reading More' in Ovid's Exile Poetry," Ramus 26.80-112.

Huret, Jules. 1891. Enquête sur l'évolution littéraire. Paris.

Jones, Christopher P. 1986. Culture and Society in Lucian. Cambridge and London. 
Lentano, Mario. 2018. Nomen. Bologna.

Pernot, Laurent. 2018. L'Art du sous-entendu. Paris.

Schiesaro, Alessandro. 2011. "Ibis redibis," MD 67.79-150.

${ }^{1}$ All three works are cited in Jacques André's editions as found in the bibliography.All translations are my own.

${ }^{2} \operatorname{Tr}$. 3.11.19-20: Et tamen est aliquis qui uulnera cruda retractet, / soluat et in mores ora diserta meos (And yet there is someone to come back and touch my raw wounds and give free rein to his eloquent mouth against my behaviour).

${ }^{3}$ « To name an object is to remove three quarters of the enjoyment of the poem, which is made of the joy of gradually guessing; to suggest it : that is the dream. » From an interview with Jules Huret, in Jules Huret 1891.60.

${ }^{4}$ Respectively Pernot 2018.113-146 and 142-146. To help me understand this concept better, Laurent Pernot generously referred me also to Culture and Society in Lucian by Christopher P. Jones (1986). Jones explains how and why the rhetorician and satirist Lucian ostensibly refuses to give the name of some of the characters he attacks.

5 Mario Lentano (2018.163-172) indirectly gave me the idea in the chapter "Censurare il nome" of his recent book Nomen.

${ }^{6}$ My translation. 